Original Research Paper

\title{
Plant Materials Transferred Management: A part of $e x$-situ conservation business process of Cibodas Botanic Gardens
}

\author{
Imawan Wahyu Hidayat ${ }^{1 *}$, Yudi Suhendri ${ }^{2}$ \\ ${ }_{1,2}$ Cibodas Botanic Gardens, Indonesian Institute of Sciences \\ ${ }^{1}$ Research Center for Plant Conservation and Botanic Garden, Indonesian Institute of Sciences
}

\section{Article history}

Received: October $9^{\text {th }}, 2019$

Revised: January $15^{\text {th }}, 2020$

Accepted: January $22^{\text {th }}, 2020$

Published : January $28^{\text {th }}, 2020$

*Corresponding Author:

Imawan Wahyu Hidayat, Cibodas Botanic Gardens Research Center for Plant Conservation and Botanic Garden, Indonesian Institute of Sciences;

Email: imaw001@lipi.go.id

\begin{abstract}
One of the botanic gardens businesses is socializing cultivated plants from the garden to be further utilized, especially for reforestation (and other conservation purposes), research and educational purposes. This socialization can be conducted through seeds exchange and plant (and parts) that transferred for various users. Cibodas Botanic Gardens (CBG), as one of the Indonesian botanic gardens, is also conducted this activity. Plant materials and so the data needed for these purposes are recorded in the material(s) transfer agreement (MTA). The study aimed to analyze the number, type, and species of transferred plant materials and the data, the background of the applicants and for what purpose of the materials is needed based on MTA's documents. This study conducted through a quantitative descriptive method based on the materials transferred from 2013 to 2018 . The results described that, for six years, the number of MTA was 86 documents, with 81 applicants. The applicants from local were $92.6 \%$ and foreign such as from China, Netherlands and Japan were $7.4 \%$. For six last years, the transferred materials included 1,205 in the form of living plants, 201 specimens in form of herbarium, 8,605 specimens in the form of seeds, many thousands various unit of part of plant, plant propagation unit and other plant materials (i.e. mycorrhiza, fungi/ lichen/ moss, rhizoid and thallus, and ascoma), and 63 unit in the form of data and other information. The results expected to be able to describe the contribution range of $\mathrm{CBG}$, especially in ex-situ plant conservation and the data, both on the local and international scale.
\end{abstract}

Keywords: plant materials; material(s) transfer agreement (MTA); ex-situ plant conservation; Cibodas Botanic Gardens (CBG)

\section{Introduction}

In the early establishment, Cibodas Botanic Gardens (CBG) was intended as a place of acclimatization of types of plants from foreign which has high value and economic importance, such as quinine tree (Cinqueona calisaya), tea (Camellia sinensis), pine (Pinus merkusii) and resin tree (Agathis spp.). In the next development, $\mathrm{CBG}$ has grown as one of the government institutions which have the main duty and function in $e x$ situ plant conservation, research, education, eco-tourism and environmental services (LIPI, 2016).

In recent years, CBG has conducted several $e x$ situ plant conservation activities with a focus on Sumatran mountainous plants. Ex-situ plant collections would help conserve threatened species (Richards et al., 2007), function as a source of traits for agricultural improvement (Neale \& Kremer, 2011), or has been used to propagate large numbers of individual plants for ecosystem restoration or assisted migration (Broadhurst et al., 2008; Vitt et al., 2010; Aitken \& Whitlock, 2013).
The other businesses of the botanic gardens is socializing cultivated plants from the garden to be further utilized, especially for reforestation (and other conservation purposes), research and educational programs. This socialization can be conducted through seeds and plants exchange that transferred for various users. CBG as one of the Indonesian botanic gardens, is also conducted this activity. Plants which needed for these purposes are recorded in the material(s) transfer agreement (MTA). MTA is a type of legally enforceable contract employed by research institutions and companies (or private) to set the terms under which their materials and associated data may be obtained and used by others (Henderson, 2007; Ku \& Henderson, 2007).

This type of agreements provides an instrument to protect the advantages of the owners of discoveries and inventions while promoting the data and material sharing in the research community (Bubela et al., 2015). The later is an admirable goal in an age where research is increasingly collaborative, multinational and multidisciplinary. MTA may apply to anything from materials that are simply under the control of the originator but 
have no formal intellectual property rights attached to them to proprietary materials protected by patents and trade secrets (Rodriguez, 2005).

MTA commonly place limits on the use of materials, their physical handling, and distribution to third parties. For example, the use of materials may be limited to noncommercial or preclinical research, or to specific fields of use, such as research on a specific disease. Distribution to third parties may be prohibited, or subject to permission from the provider (Bubela et al., 2015). On the other hand, MTA has a bad reputation among researchers for being overly complex and, in practice, hindering the exchange of research reagents (Mishra \& Bubela, 2014; Bubela et al., 2015). Nevertheless, the MTA remains necessary in order to protect the provider's biological resources, as well as take responsibility for the development and utilization processes. In this context, $\mathrm{CBG}$ has also applied the MTA policy in the transfer of its biological resources.

Plant materials used in those activities are recorded in MTA. This MTA is a prudence action of plants data recording, as evidence that the utilization of any form of bio-resources material in $\mathrm{CBG}$ well documented and as a contribution of plants conservation (UN, 1992). Forms of material which has been used were consisting of seedling, seeds, and part of plant materials (such as leaves, roots, stems, and fruit), mushrooms, moss, and other biological resources.

The objectives of this study were analyzed the number, type, and species of transferred plant materials, the background of the user and for what purpose of the plants is needed, based on CBG's MTA documents from 2013 to 2018. Through this study can be analyzed the utilization of plant material and user characteristics and purpose of its utilization. Furthermore, the results expected to be able to describe the contribution range of CBG, especially in ex-situ plants conservation and the data, both on the local and international scale.

\section{Materials and Methods}

\section{Study site}

The study was conducted at $\mathrm{CBG}$, Cianjur, West Java. CBG is located at $107^{\circ} 0^{\prime} 10.476^{\prime \prime} \mathrm{E}$ to $107^{\circ} 0^{\prime}$ 59.275" E and 6 $6^{\circ} 44^{\prime} 6.787^{\prime \prime} \mathrm{S}$ to $6^{\circ} 44^{\prime} 51.112^{\prime \prime} \mathrm{S}$. The location is mountainside of mount Gede and mount Pangrango, at an altitude of approximately 1,300-1,425 meters above sea level, with an area of 84.99 hectares (Widyatmoko et al., 2010). The average temperature is $20{ }^{\circ} \mathrm{C}$, humidity of $80.82 \%$ and an average rainfall of 2,950 mm per year (Registration Unit-CBG, 2018a). CBG is ex-situ plants conservation with various types of plants that mostly originated from Indonesia, more than 60\% (Registration Unit-CBG, 2018b), especially from tropical wet mountains, and other foreign countries. $\mathrm{CBG}$ is $\pm 100 \mathrm{~km}$ from Jakarta and $\pm 80 \mathrm{~km}$ from Bandung.

\section{Study framework}

In this study, MTA of CBG was referred to as document form with code FR.8.RG-6.2. (CBG document of ISO 9001:2015 section Form of Registration Unit, 2018, unpublished data), which related to the document form with code: (1) FR.8.RG-6.1.G1., external request of information data and/ or plant material; (2) FR.8.RG6.3.G2., internal request of information data and/ or plant material; (3) FR.8.RG-6.4.G3., follow up to the request of information data and/ or plant material; and (4) FR.8.RG-6.5.G4., transferred of information data and/ or plant material. The business process of this order can be described in Figure 1.

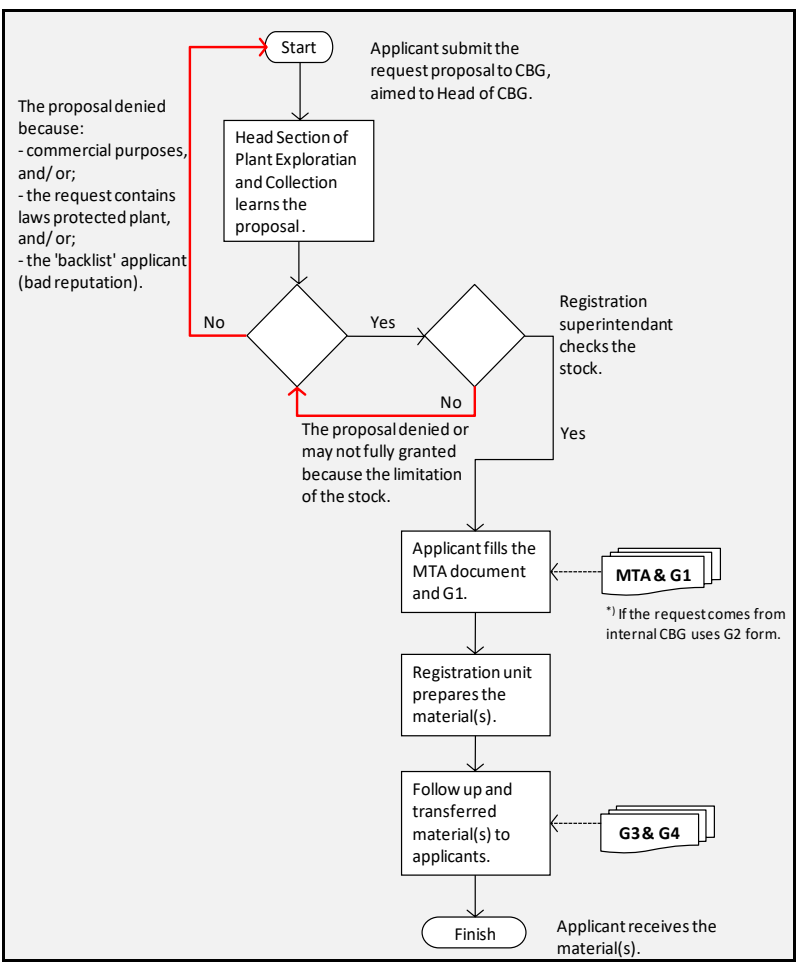

Figure 1. The business process and procedures of transferred information data and/ or plant material(s) request applied in CBG. (Source: CBG document of ISO 9001:2015 section Form of Collection Registration Unit, 2018, unpublished data).

This MTA intends to honor the letter and spirit of the 1992 Convention on Biological Diversity (CBD) (UN, 1992), Convention on International Trade in Endangered Species of Wild Fauna and Flora (CITES), and other relevant conventions and laws regarding the use of biological diversity as well as benefit-sharing. 
Material which explained in CBG's MTA includes, but is not limited to plants, parts of a plant or propagation material (such as seeds, cuttings, roots, bulbs, corms, leaves, plant tissue culture, plant herbarium or any other material of plant). Based on CBG's MTA agreement, material and any progeny or derivates thereof such modified or unmodified extracts will not be used for commercial purposes. If at any point in the future recipient wishes to commercialize the material and any progeny or derivates, the recipient must first obtain the written permission of CBG.

Any commercialization to which CBG agrees will be subject to a separate agreement between the recipient and the $\mathrm{CBG}$ consistent with the CBG's policy that benefits be shared fairly and equitably with the country of origin of the material (UN, 1992). Commercialization means the use or exploitation of genetic resources, their progeny or derivates, with the object of, or resulting in financial gain, and includes but not limited to the following activities: sale, applying for, obtaining or transferring intellectual property rights or other tangible or intangible rights by sale or license or any other manner, commencement of product development, conducting market research, and seeking pre-market approval (Medaglia \& Silva, 2007; CBG document of ISO 9001:2015, section Form of Collection Registration Unit, 2018, unpublished data).

\section{Data analysis}

The subject of this study was CBG's MTA and supporting documents (G1, G2, G3, and G4) which recorded from 2013 to 2018. CBG's MTA was a contractual document between CBG and applicant/ recipient candidate/ user regarding all material form in CBG which ordered, requested or transferred. MTA and supporting documents have contained: (i) applicant personal data, (ii) the purposes of the applicant, (iii) the type of material (i.e. data, information, and (part of) plant material), (iv) the number of material, and (v) the plant species.

The data will be analyzed quantitative-descriptive each year of the time period. The trend of the increasing number of the request was done through a simple regression analysis by the formula: $y_{i}=a+b x_{i}$. The results will describe the applicants' background, what purposes those materials are needed and the description of the materials transferred by CBG. Furthermore, these also can be claimed as CBG's contribution to plant conservation through the information and knowledge transfer about CBG's plants' property to the wider community.

\section{Results and Discussion}

\section{The number of request and the background applicant}

Based on the 2013 to 2018 period, the total number of CBG's MTA was 86 documents (Figure 1). There were 4 documents in 2013, 8 documents in 2014, 10 documents in 2015, 17 documents in 2016, 22 and 25 documents in 2017 and 2018. Totally, the transferred materials were included 1,205 in the form of living plants, 201 specimens in form of herbarium, 8,605 specimens in the form of seeds, many thousands various unit of part of plant, plant propagation unit and other plant materials (i.e. mycorrhiza, fungi/ lichen/ moss, rhizoid and thallus, and ascoma), and 63 unit in the form of data and other information (Table 1).

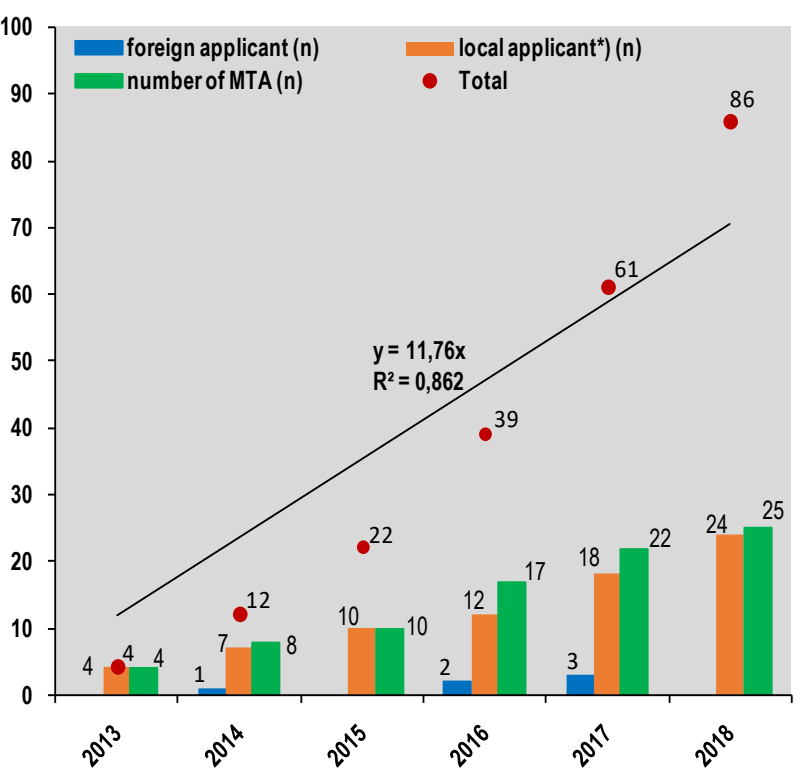

Figure 1. The number of MTA published documents trends from 2013 to 2018. (Note: *) An applicant may request more than once in a year period and the number of MTA documents also follows, but only counted as one applicant).

The data showed that each year plants request was tended to rise (Figure 1). These results can be explained, among others, information disclosure that shared by CBG in various media, especially in https:// sindata.krcibodas.lipi.go.id/ Cibodas-Botanic-GardensRecord/CBGR/index.php, regarding the richness of collections which can be accessed by anyone. This openness (especially the information) is giving a widen range potential users and to attract allies and customers (Shapiro et al., 1999). The establishment of new botanic gardens has also contributed of the rise. Enrichment of the plant collection through plant seeds exchange is one of the botanic gardens businesses in order to develop the 
conservation value of the garden (Davis, 2008; BGCI, 2012; Purnomo et al., 2015).

The local applicants were still dominated plants request with 75 different applicants compared to foreign with 6 applicants. An applicant may request more than once in a year period and the number of MTA documents also follows, but only counted as one applicant. This case occurs a difference between MTA published documents (86) and the number of applicants (81), especially local (75). The record also notes that education and research institution mostly applies the agreement. Local institution applicants recorded in MTA were Samosir Botanic Gardens, Center of Plant Conservation-Bogor Botanic Gardens, Baturaden Botanic Gardens, Kuningan Botanic Gardens, Wamena Biological Gardens, Forest Research and Development Center - Ministry of Environment and Forestry Center of Geology Survey Bandung, and Herbarium Bandungense.
Moreover, some individual has also apply the agreements. These dominated from a research institution, university and other institution, such as students from Padjadjaran University, Brawijaya University, researchers from Indonesian Ornamental Crops Research Institute, etc. Furthermore, six agreements from foreign which established were one institution in 2014 with South China Botanic Garden, two agreements in 2016 with a student of Mie University of Japan and a Ph.D student of Leiden University of Netherlands. In 2017, the number of agreement was three documents, a Ph.D student of Naturalis Biodiversity Center of Leiden, Netherlands and researcher's staff of National Museum of Nature and Science, and Tsukuba Botanical Garden, the last both are from Japan. Foreign applicants have contributed $7.4 \%$ of the total applicant or $6.9 \%$ of the total MTA documents published by CBG from 2013 to 2018.

Tabel 1. The detail description of transferred materials of CBG from 2008 to 2018.

\begin{tabular}{|c|c|c|c|c|c|c|c|}
\hline \multirow{2}{*}{ Information } & \multirow{2}{*}{ Type } & \multicolumn{6}{|c|}{ Year } \\
\hline & & 2013 & 2014 & 2015 & 2016 & 2017 & 2018 \\
\hline \multirow{11}{*}{ Plant (and parts): } & a full living plants $(n)$ & - & 27 & 212 & 70 & 216 & 680 \\
\hline & herbarium $(n)$ & - & - & - & - & 201 & - \\
\hline & leaf (and parts) & $6 \mathrm{~kg}$ & 3 sheets & 58 sheets & 284 sheets & 149 sheets & 73 sheets \\
\hline & branch (and parts) & - & $10 \mathrm{~kg}$ & $13.12 \mathrm{~kg}$ & - & 4 pcs & - \\
\hline & stem (and parts) & - & 7 pcs & - & 67 pcs & $91 \mathrm{pcs}$ & $2 \mathrm{pcs}$ \\
\hline & root (and parts) & - & - & $2 \mathrm{pcs}$ & 5 pcs & $5 \mathrm{~cm}$ & 14 pcs \\
\hline & flower (and parts) & - & - & & 117 pcs & 196 pcs & $61 \mathrm{pcs}$ \\
\hline & fruit (and parts) & - & - & $58 \mathrm{pcs}$ & $184 \mathrm{pcs}$ & - & $58 \mathrm{pcs}$ \\
\hline & seeds $(n)$ & 40 & 920 & 20 & 330 & 6,959 & 336 \\
\hline & $\begin{array}{l}\text { package of seeds (very } \\
\text { small to small size or } \\
\text { spores etc.) }\end{array}$ & 11 & 9 & 11 & - & 3 & - \\
\hline & shoots $(n)$ & - & 235 & - & 2 & - & - \\
\hline \multirow{2}{*}{$\begin{array}{l}\text { Plant propagation } \\
\text { material: }\end{array}$} & cutting $(n)$ & - & 11 & & - & 10 & - \\
\hline & grafting $(n)$ & - & - & 1 & - & - & - \\
\hline \multirow[t]{4}{*}{ Other plant material: } & mychorriza ( $n$-colony) & - & 15 & - & 92 & - & - \\
\hline & $\begin{array}{l}\text { fungi/ lichen/ moss } \\
\text { ( } n \text {-colony) }\end{array}$ & - & - & 4 & 235 & 24 & 9 \\
\hline & rhizoid+thallus $(n)$ & - & - & - & 30 & 12 & - \\
\hline & $\operatorname{ascoma}(n)$ & - & - & - & 20 & - & - \\
\hline \multirow{4}{*}{$\begin{array}{l}\text { Data and other } \\
\text { information: }\end{array}$} & record file $(n)$ & - & - & - & - & - & 11 \\
\hline & record data $(n)$ & - & - & - & - & - & 22 \\
\hline & visual data $(n)$ & - & - & - & - & - & 5 \\
\hline & picture $(n)$ & - & - & - & - & - & 25 \\
\hline
\end{tabular}

Source: data was compiled and resolved from MTA, G1, G2, G3, and G4 documents of CBG 2013 to 2018. (Note: Each granted request may showed different unit of materials depends on the stock and simplified the calculation. pcs $=$ pieces; $n=$ number). 


\section{The various type of materials}

Furthermore, the plant materials which requested from foreign can be seen in Table 2. Mostly part of the plant materials requests in form of leaf (and parts) sheet. Based on the agreement, these materials used for research purposes and educational interests.

Leaves material were allowed because of the lack of plants stock in the nursery, so only leaves that can be granted by $\mathrm{CBG}$. In addition, leaves material are easy to transport and does not require special treatment than whole a plant, usually inserted in plastic or large paper envelope. Based on the type of material, seeds and packages of seeds were the highest requests from the user. Transferred seeds were 8,605 pieces and the package of seeds as much as 34 packages (if each packaged contains more than 20 pieces, so the number of seeds was more than 680 pieces of seeds).

Package of seeds was established on seed material which very small to small size. It was conducted because the difficulty to count one by one of seed and/ or the seed material in large numbers and the stock at the garden was abundant. High requests for materials in the form of seeds can be understood because seeds can be wrapped, transferred and delivered easily, and do not require much space. In addition, through the seeds, they

Table 2. MTA information applied by foreign applicants.

\begin{tabular}{|c|c|c|c|c|c|}
\hline $\begin{array}{l}\text { Institution/ } \\
\text { individual }\end{array}$ & Species & Family & $\begin{array}{l}\text { Type of } \\
\text { materials }\end{array}$ & $n$ & $\begin{array}{l}\text { Purpose of the } \\
\text { request }\end{array}$ \\
\hline \multirow{4}{*}{$\begin{array}{l}\text { South China } \\
\text { Botanic Garden }\end{array}$} & Musa acuminata & Musaceae & leaf (and parts) & 1 & \multirow{4}{*}{$\begin{array}{l}\text { Research interest on } \\
\text { mycorrhiza attaced to } \\
\text { Musa spp. }\end{array}$} \\
\hline & Musa uranoscopus & Musaceae & leaf (and parts) & 1 & \\
\hline & Musa sp. & Musaceae & leaf (and parts) & 1 & \\
\hline & Mycorrhiza in wild Musa spp. & - & colony & 10 & \\
\hline \multirow{14}{*}{$\begin{array}{l}\text { A Ph.D student of } \\
\text { Mie University, } \\
\text { Japan }\end{array}$} & Castanopsis argentea & Fagaceae & leaf (and parts) & 30 & \multirow{14}{*}{$\begin{array}{l}\text { Research interest on } \\
\text { tropical mountainous } \\
\text { plant species. }\end{array}$} \\
\hline & Castanopsis javanica & Fagaceae & leaf (and parts) & 66 & \\
\hline & Codiaeum variegatum & Euphorbiaceae & leaf (and parts) & 20 & \\
\hline & Hibiscus indicus & Malvaceae & leaf (and parts) & 9 & \\
\hline & Acalypha amentacea & Euphorbiaceae & leaf (and parts) & 10 & \\
\hline & Breynia microphylla & Phyllanthaceae & leaf (and parts) & 8 & \\
\hline & Acanthus montanus & Acanthaceae & leaf (and parts) & 8 & \\
\hline & Acalypha $\times$ cristata & Euphorbiaceae & leaf (and parts) & 12 & \\
\hline & Morus alba & Moraceae & leaf (and parts) & 8 & \\
\hline & Aglaia rimosa & Meliaceae & leaf (and parts) & 20 & \\
\hline & Acalypha hispida & Euphorbiaceae & leaf (and parts) & 10 & \\
\hline & Solanum sp. & Solanaceae & leaf (and parts) & 5 & \\
\hline & Hibiscus sp. & Malvaceae & leaf (and parts) & 8 & \\
\hline & Euphorbia pulcherrima & Euphorbiaceae & leaf (and parts) & 8 & \\
\hline \multirow{3}{*}{$\begin{array}{l}\text { A Ph.D student of } \\
\text { Leiden University, } \\
\text { Netherlands }\end{array}$} & Trigonostemon sp. & Euphorbiaceae & leaf (and parts) & 2 & \multirow{3}{*}{$\begin{array}{l}\text { Research interest on } \\
\text { tropical mountainous } \\
\text { plant species. }\end{array}$} \\
\hline & Ostodes paniculata & Euphorbiaceae & leaf (and parts) & 2 & \\
\hline & Phyllanthus sp. & Phyllanthaceae & leaf (and parts) & 2 & \\
\hline \multirow{8}{*}{$\begin{array}{l}\text { A Ph.D student of } \\
\text { Naturalist } \\
\text { Biodiversity } \\
\text { Center Leiden, } \\
\text { Netherlands }\end{array}$} & Bazzania japonica & Lepidoziaceae & herbarium & 16 & \multirow{8}{*}{$\begin{array}{l}\text { Research interest on } \\
\text { tropical mountainous } \\
\text { plant species. }\end{array}$} \\
\hline & Bazzania sp. & Lepidoziaceae & herbarium & 15 & \\
\hline & Bazzania sp. (2) & Lepidoziaceae & herbarium & 8 & \\
\hline & Bazzania tridens & Lepidoziaceae & herbarium & 27 & \\
\hline & Heteroscyphus coalitus & Geocalycaceae & herbarium & 16 & \\
\hline & Pyrrhobryum spiniforme & Rhizogoniaceae & herbarium & 60 & \\
\hline & Thuidium cymbifolium & Thuidiaceae & herbarium & 16 & \\
\hline & Thuidium pristocalyx & Thuidiaceae & herbarium & 20 & \\
\hline \multirow{2}{*}{$\begin{array}{l}\text { National Museum } \\
\text { of Nature and } \\
\text { Science, Japan }\end{array}$} & Todea barbara & Osmundaceae & package of spores & 1 & \multirow{2}{*}{$\begin{array}{l}\text { Research interest on } \\
\text { tropical mountainous } \\
\text { plant species. }\end{array}$} \\
\hline & Alnus japonica & Betulaceae & leaf (and parts) & 1 & \\
\hline \multirow{3}{*}{$\begin{array}{l}\text { Tsukuba Botanical } \\
\text { Garden, Japan }\end{array}$} & Amorphophallus titanum & Araceae & leaf (and parts) & 1 & \multirow{3}{*}{$\begin{array}{l}\text { Research interest on } \\
\text { tropical mountainous } \\
\text { plant species. }\end{array}$} \\
\hline & Amorphophallus asper & Araceae & leaf (and parts) & 1 & \\
\hline & Amorphophallus sp. & Araceae & leaf (and parts) & 1 & \\
\hline
\end{tabular}


can be sown and cultivated into plants that have similar characteristics to its parent in the garden.

According to the policy of the Head of $\mathrm{CBG}$, transferred (living) plants, especially for a complete living plant, is mostly given to fellow of the botanical garden institutions in Indonesia, and those depend on the number of the collections of CBG. Plants request among fellow members is usually used in the context of enrichment of the collections and for research and education purposes. The second policy is if the number of plants was abundant in the nursery or and/ or the technique of breeding is relatively easy, and then the request may be granted (especially for a complete living plant request). The next policy is if the number of plants were just a few (five specimens or less) and/ or difficult to breed it, the possibility of the request will be reduced from the requested, or even denied. of a plant (such leaf, branch, flower, fruit, etc.) that listed in the law was still possible to be granted, for example, Castanopsis argentea and Castanopsis javanica, but it also depends on the stock and plant collection sensitivity. If the main plant is too vulnerable, then only a limited number of the leaves material will granted. Nevertheless, this granting is only valid if the user guarantees that the material is used for conservation or research and education purposes only.

Plant(s) and/ or part(s) of the plant granted to the applicant were not charged because this is a part of the contribution of $\mathrm{CBG}$ in conservation, research, and education. After the request granted then all responsibility for shipping and licensing is borne by the applicant and CBG does not serve this. These policies also listed in CBG's Documents of ISO 9001:2015 Section Form of Registration Unit.

Table 3. The five most requested plant species in form of plant, fruit, leaf and seeds.

\begin{tabular}{|c|c|c|c|c|c|}
\hline Species & Family & $\begin{array}{c}\text { Plant } \\
\text { (and parts) } \\
(n)\end{array}$ & $\begin{array}{c}\text { Fruit } \\
\text { (and parts) } \\
(n)\end{array}$ & $\begin{array}{c}\text { Leaf } \\
\text { (and parts) } \\
(n)\end{array}$ & $\begin{array}{c}\text { Seeds } \\
(n)\end{array}$ \\
\hline Pinanga javana & Arecaceae & 150 & & & \\
\hline Handroanthus chrysotrichus & Bignoniaceae & 50 & & & \\
\hline Prunus cerasoides & Rosaceae & 46 & & & \\
\hline Crinum sp. & Amaryllidaceae & 35 & & & \\
\hline Altingia excelsa & Altingiaceae & 32 & & & \\
\hline Elaeagnus latifolia & Elaeagnaceae & & 58 & & \\
\hline Amorphophallus titanum & Araceae & & 50 & & \\
\hline Calliandra sp. & Leguminosae & & 25 & & \\
\hline Ficus variegata & Moraceae & & 13 & & \\
\hline Muehlenbeckia platyclados & Polygonaceae & & 7 & & \\
\hline Castanopsis javanica & Fagaceae & & & 66 & \\
\hline Castanopsis argentea & Fagaceae & & & 30 & \\
\hline Codiaeum variegatum & Euphorbiaceae & & & 20 & \\
\hline Aglaia rimosa & Meliaceae & & & 20 & \\
\hline Acalypha $\times$ cristata & Euphorbiaceae & & & 12 & \\
\hline Pittosporum moluccanum & Pittosporaceae & & & & 500 \\
\hline Castanopsis argentea & Fagaceae & & & & 130 \\
\hline Platea latifolia & Icacinaceae & & & & 101 \\
\hline Symplocos costata & Symplocaceae & & & & 85 \\
\hline Lithocarpus pallidus & Fagaceae & & & & 68 \\
\hline
\end{tabular}

However, personal requests for complete living plants are still possible but must be approved by the Head of CBG, and not necessarily to be granted. The possible granted plants request is excluded plant species that protected by Indonesian laws (Peraturan Pemerintah Republik Indonesia Nomor 7 Tahun 1999 and updated to Peraturan Menteri Lingkungan Hidup dan Kehutanan Republik Indonesia Nomor P.106/ MENLHK/SETJEN/ KUM.1/8/2018). The request of part
For commercial users, CBG has also conducted the service. The activities were conducted by the Services and Information Section of CBG while still obeying previous policy principles, but not further discussed in this paper.

Based on the MTA documents, it has discovered that the most requested a complete plant species was Pinanga javana (Arecaceae), for fruit request was Elaeagnus latifolia (Elaegnaceae), for leaf request was 
Castanopsis javanica (Fagaceae), and for seeds was Pittosporum moluccanum (Pittosporaceae). The details of the most requested plant can be seen in Table 3 .

The results can be described that the stock of these species was abundant, so CBG can comply with the request. Moreover, most of these species were wettropical mountainous plants so these were appropriate to be planted in the new location such as Baturraden and Kuningan Botanic Gardens as the plants' collection enrichment that has a similarity of the elevation and relative microclimate condition. This uniqueness and the native characters for some species such as $C$. javanica, A. titanum, and $S$. costata were an interesting object to be studied further. This was also driven by the request of the above species.

These processes, mechanisms and the policy of MTA were also conducted by other botanic gardens, especially those coordinated by the Indonesian Institute of Sciences (LIPI), that are Center of Plant Conservation-Bogor Botanic Gardens, Cibodas Botanic Gardens, Purwodadi Botanic Gardens, and Eka KaryaBali Botanic Gardens. In general, these botanic gardens were not charging any cost in seed and plant exchange, excluded for the commercial user.

Furthermore, CBG has also denied five requests in these periods. Three requests from local and two from foreign institutions/individuals. This conducted because the requests incompatible with the $\mathrm{CBG}$ policies and/ or indicated violated the law. These mostly caused by the requested plant were limited stock, protected plant(s) or not able to prove the permit from the authorities (such as The Ministry of Environment and Forestry of Indonesia, Research Center of Biology-Indonesian Institute of Sciences (LIPI), Plant Conservation Center-Bogor Botanic Gardens). In order to take care of the credibility and reputation of the applicants than the names were not mentioned.

CBGs MTA is not to prevent researchers, students or other subjects from obtaining plants or plant materials from $\mathrm{CBG}$, but it is a prudence action and well-documented process of how plants or plant materials of CBGs going to outwards. As a conservation institution, directly or indirectly, $\mathrm{CBG}$ is partly responsible for its plants and the materials. Despite the fact that CBG has difficulty controlling the development and utilization of plants and materials that have been transferred to users, although clearly stated in MTA, CBG should get benefit share, if the plants and materials can be developed and/or advanced utilization by users.

Benefits are arising from the utilization of such knowledge, innovations, and practices (UN, 1992; Streitz \& Bennet, 2003; Rodriguez, 2005; Mirowsky, 2008). Benefits can be also arising from the commercial and other utilization of genetic resources with the Contracting Party providing such resources. Such sharing shall be upon mutually agreed terms (Streitz \& Bennet, 2003; Rodriguez, 2005; Mirowsky, 2008).

CBGs MTA document has been composed by holding several principles, which are simple, management of risks should be proportionate to the type and likelihood of benefits and avoids reach-through claims (Mishra \& Bubela, 2014; Bubela et al., 2015). MTAs should also be commensurate with a realistic assessment of the risks and benefits to the institutions, both in terms of legal liabilities and potential revenue generation. Institutional contracts staff should evaluate the presence or likelihood of the following categories of risks relative to the likely benefits to accrue to the institution and/or its researchers and use MTAs or simpler agreements.

Through the MTA, CBG is widely open up for anyone or institution that will and wants to engage the activities especially in the field of plant research and education, through mutually beneficial agreements. CBG adopts these MTA's simple agreements in cases where the risk is low and the benefits are non-commercial interest. Even though, CBG still concerns those cases where more complex agreements are warranted, especially in relation to industry and in contexts closer to commercial development and/or clinical application, and violation of the efforts of ex-situ plant conservation.

\section{Conclusions}

CBG has conducted plant transferred materials as a part of the efforts of ex-situ plant conservation. In the past six years, CBG has served 86 requests of plant materials and the data, from local and foreign applicants. Most of the request dominates from local individuals and institutions. The most requested materials in the form of seeds. Those materials needed in order to develop their research and educational purposes, especially in tropical mountainous plant species. P. javana (Arec.), E. latifolia (Elaeg.), C. javanica (Fag.), and P. moluccanum (Pitt.) are most requested plant species that characterized of tropical mountainous plants. Even clearly stated in MTA documents, however, CBG has difficulty controlling the development and utilization of plants and materials that have been transferred to recipients. These results expected to be able to describe the contribution range of CBG, especially in ex-situ plant conservation and the data, both on the local and international scale.

\section{Acknowledgement}

The authors are thankfull towards all staff of CBGs' Registration Unit, Didi Rasidi, Habibulloh, Puji Soepriati, Dimas Ardiyanto, Neneng Ine Kurnita, Bahtiar, and Agus Darmawan for cooperation in data compilation. Our gratefull also delivered towards former 
Head of CBG, Dr. Didik Widyatmoko, Mr. Agus Suhatman, and Dr. R. Hendrian for the inputting and the valuable considerations in accomodating the process and documentation of transferred materials business in CBG.

\section{References}

Aitken, S.N. \& Whitlock, M.C. (2013). Assisted gene flow to facilitate local adaptation to climate change. Annual Review of Ecology and Systematics 44: 367-388. DOI: https://doi.org/10.1146/ annurev-ecolsys-110512-135747

[BGCI] Botanic Gardens Conservation International. (2012). International Agenda for Botanic Gardens in Conservation (2nd Ed.). Richmond. Botanic Gardens Conservation International, 48 pp. ISBN: 978-1-905164-45-5. Accessed from: https://www.bgci.org/files/Worldwide/News/Sept Dec12/international_agenda_web.pdf

Broadhurst, L.M., Lowe, A., Coates, D.J., Cunningham, S.A., McDonald, M., Vesk, P.A. \& Yates, C. (2008). Seed supply for broadscale restoration: maximizing evolutionary potential. Evolutionary Applications 1 (4): 587-597. DOI: https://doi.org/ $\underline{10.1111 / \mathrm{j} .1752-4571.2008 .00045 . \mathrm{x}}$

Brummer, E.C., Barber, W.T., Collier, S.M., Cox, T.S., Johnson, R., Murray, S.C., Olsen, R.T., Pratt, R.C. \& Thro, A.M. (2011). Plant breeding for harmony between agriculture and the environment. Frontiers in Ecology and the Environment 9 (10): 561-568. DOI: https://doi.org/10.1890/100 $\underline{225}$

Bubela, T., Guebert, J. \& Mishra, A. (2015). Use and misuse of material transfer agreements: Lessons in proportionality from research, repositories, and litigation. PLoS Biology 13 (2): e1002060. DOI: https://doi.org/10.1371/journal.pbio. 1002060

[CBG] Cibodas Botanic Gardens. (2018). CBG's Documents of ISO 9001:2015 Section Form of Registration Unit: Material Transfer Agreement. Cianjur. Cibodas Botanic Gardens, Indonesian Institute of Sciences. [unpublished].

[CITES] Convention on International Trade in Endangered Species of Wild Fauna and Flora. (2019). Accessed from: https://cites.org/eng/app/ appendices.php.

Davis, K. (2008). A CBD manual for botanic gardens. Richmond. Botanic Gardens Conservation
International, 36 pp. ISBN: 978-1-905164-29-5. Accessed from: http://www.amjb.unam.mx/repo sitorio/documentos/polit_doc/internacionales/CB D_manual_for_botanic_gardens.pdf

Henderson, J. (2007). Counterpoint: MTAs are a practical necessity. Nature Biotechnology 25 (7): 722-724. DOI: https://doi.org/10.1038/nbt0707722

[IUCN] International Union for the Conservation of Nature. (2019). The IUCN Red List of Threatened Species. Accessed from: https://www.iucnredlist. org/

$\mathrm{Ku}$, K. \& Henderson, J. (2007). The MTA-rip it up and start again? Nature Biotechnology 25 (7): 721-722. Accessed from: https://www.nature. com/articles/nbt0707-721b.pdf?draft=journal

[LIPI] Lembaga Ilmu Pengetahuan Indonesia. 2016. Peraturan Kepala LIPI Nomor 3 Tahun 2016 tentang Organisasi dan Tata Kerja Balai Konservasi Tumbuhan Kebun Raya Cibodas. Berita Negara RI Tahun 2016 Nomor 304. Direktorat Jenderal Peraturan PerundangUndangan Kementerian Hukum dan HAM RI. Jakarta. Accessed from: https://jdih.lipi.go.id/pera tu ran/2016_perka_3.pdf

Menteri Lingkungan Hidup dan Kehutanan RI. Peraturan Menteri Lingkungan Hidup dan Kehutanan Republik Indonesia Nomor P.106/MEN LHK/SETJEN/KUM.1/12/2018 tentang Jenis Tumbuhan dan Satwa yang Dilindungi. Berita Negara RI Tahun 2019 Nomor 32. Direktorat Jenderal Peraturan Perundang-Undangan Kementerian Hukum dan HAM RI. Jakarta. Accessed from: https://graccess.co.id/assets/document/Per men P106.pdf

Mirowski, P. (2008). Livin' with the MTA. Minerva 46 (3): 317-342. DOI: https://dx.doi.org/10.1007/ s11024-008-9102-2

Mishra, A. \& Bubela, T. (2014). Legal agreements and the governance of research commons: Lessons from materials sharing in mouse genomics. OMICS A Journal of Integrative Biology 18 (4): 254-273. DOI: https://doi.org/10.1089/omi.2013. $\underline{0158}$

Neale, D.B. \& Kremer, A. (2011). Forest tree genomics: growing resources and applications. Nature 
Reviews Genetics 12 (2): 111-122. DOI: https:// doi.org/10.1038/nrg2931

Peterson, G.D., Cumming, G.S. \& Carpenter, S.R. (2003). Scenario planning: a tool for conservation in an uncertain world. Conservation Biology 17 (2): 358-366. DOI: https://doi.org/10.1046/j. 1523-1739.2003.01491.x

Presiden Republik Indonesia. Peraturan Pemerintah Republik Indonesia Nomor 7 Tahun 1999 tentang Pengawetan Jenis Tumbuhan dan Satwa. Lembaran Negara RI Tahun 1999 Nomor 14. Sekretariat Negara. Jakarta. Accessed from: http://www.advokatnabali.com/pdf/doc2/PP\%207 -1999\%20ttg\%20Pengawetan\%20Jenis\%20Tum buhan\%20dan\%20Satwa.pdf

Purnomo, D., Magandhi, M., Kuswantoro, F., Risna, R.A. \& Witono, J.R.. (2015). Pengembangan koleksi tumbuhan kebun raya daerah dalam kerangka strategi konservasi tumbuhan di Indonesia. Buletin Kebun Raya 18 (2): 111-124. Accessed from: https://jurnal2.krbogor.lipi.go.id/ index.php/buletin/article/view/99/0

Richards, C.M., Antolin, M.F., Reilley, A., Poole, J. \& Walters, C. (2007). Capturing genetic diversity of wild populations for ex-situ conservation: Texas wild rice (Zizania texana) as a model. Genetic Resource and Crop Evolution 54 (4): 837-848. DOI: https://doi.org/10.1007/s10722-006-9167-4

Registration Unit-CBG. (2018a). Monthly reports of plants collection richness of CBG of 2018. Cianjur. Cibodas Botanic Gardens. [Indonesian] [Unpublished]

Registration Unit-CBG. (2018b). Annual reports of microclimates of CBG from 2012 to 2018: Form D10. Cianjur. Cibodas Botanic Gardens. [Indonesian] [Unpublished]

Rodriguez, V. (2005). Material transfer agreements: open science vs. proprietary claims. Nature Biotechnology 23: 489-491. DOI: https://doi.org/ 10.1038/nbt0405-489

Shapiro, C., Varian, H.R. \& Becker, W.E. (1999). Information rules: a strategic guide to the network economy. Journal of Economic Education 30: 189-190. DOI: https://doi.org/10.1080/002204899 $\underline{09595956}$
Streitz, W.D. \& Bennett, A.B. (2003). Material transfer agreements: A University perspective. Plant Physiology 133 (1): 10-13. DOI: https://doi.org/ $\underline{10.1104 / p p .103 .026658}$

[UN] United Nations. (1992). Convention on Biological Diversity. New York. United Nations. Accessed from: https://www.cbd.int/doc/legal/cbd-en.pdf

Widyatmoko, D., Suryana, N., Suhatman, A. \& Rustandi (Eds.). (2010). List of Living Plants Collection Cultivated in Cibodas Botanic Gardens. Cianjur. Cibodas Botanic Gardens, Indonesian Institute of Sciences, 131 pp. ISBN: 978-979-99448-5-6. Accessed from: https://scholar.google.com/scho lar?cluster $=13664307329458822470 \& \mathrm{hl}=\mathrm{en} \& \mathrm{i}=$ scholarr

Vitt, P., Havens, K., Kramer, A.T., Sollenberger, D. \& Yates, E. (2010). Assisted migration of plants: changes in latitudes, changes in attitudes. Biological Conservation 143 (1): 18-27. DOI: ht tps://doi.org/10.1016/j.biocon.2009.08.015 